\title{
The Perception on Indie Films of Selected Intramuros Based Audiences
}

\author{
Gil Gerald N. Fuentes, Dwight Roussel Glenn M. Labilles, and Rowena Capulong Reyes
}

\begin{abstract}
Stuart Hall's Reception Study Theory explains that the reader / viewer interpret the meaning of the text based on their individual cultural background and life experiences. In essence, the meaning of a text is not inherent within the text itself, but is created within the relationship between the text and the reader/ viewer. The purpose of the current research is to find out the perceptions of Intramuros based Audiences on Indie films. A total of 152 Communication students were selected through a non-probability, purposive sampling. A two part survey questionnaire was used to measure the knowledge, attitude and practices of Communication students towards independent films. Pearson Correlation and comparison of means, cross-tabulations, and frequency tables were used. Frequency distributions were used to compute their response. Readiness of the respondents to embrace this new industry has been shown in this research study.
\end{abstract}

Index Terms-Communication students, indie films, intramuros, perception.

\section{INTRODUCTION}

Film, often called movie or motion picture, by its general definition is a series of still images shown simultaneously to simulate the illusion of movement. Its early beginnings as said by Brian Manley [1] "cannot be credited to one individual as an oversimplification of any history tries to do." Defending the fact, claiming that its origins are combination of the efforts of different inventions accumulated throughout the years.

Throughout the years, film has diversified into two major classifications, the mainstream and the independent. Mainstream films are such movies that are big budgeted, produced by major production companies and widely released in cinemas such as the Lucas' and the Spielberg films and the like. Such films are released in cinemas for a short period of time and are tailored to attract customers at a global scale. Whereas independent films are the opposite, being produced outside a major studio and often tackles topics that the mainstream people do not usually take. It is known to be the "mirror to reality" as it endeavors such plots about societal issues and culture, going against the usual Hollywood-esque type of filming as it focuses on a rather uncanny approach in its production.

Today, despite of several problems from the distinction of mainstream from Independent cinema, it continues to grow

Manuscript received October 7, 2013; revised December 3, 2013. This work was supported in part by the professors of the Institute of Communication of the Colegio de San Juan de Letran.

Gil Gerald N. Fuentes, Dwight Roussel Glenn M. Labilles, and Rowena Capulong Reyes are with the Colegio de San Juan de Letran - Manila (e-mail gilgerald.fuentes@gmail.com). and make a mark of its own. According to Xu Yaping's [3], independent cinema serves as the realistic aesthetics emphasizing the filming subject's relation with objectivity. It is the genre wherein we could show the artsy, classy and the surreal reality of one's society.

\section{AUDIENCE's OVERVIEW ON INDIE FILMS}

The study was conducted specifically on the Communication Students (or at least students within a communication related course) of Intramuros. A quick tabulation showed that $52 \%$ of the respondents were female, $39 \%$ were male and a small $9 \%$ were people who did not fill up the contact details.

TABLE I: COMMUNICATION STUDENTS’ RESPONES ON INDIE FILMS

\begin{tabular}{|c|c|c|c|c|c|}
\hline & & & $\begin{array}{c}152 \\
\text { Respondents }\end{array}$ & & \\
\hline & $\begin{array}{c}\text { \# Who Like } \\
\text { Watching } \\
\text { Films }\end{array}$ & $\begin{array}{l}\text { \# Who } \\
\text { Watch } \\
\text { Movies in } \\
\text { Movie } \\
\text { Houses }\end{array}$ & $\begin{array}{c}\text { \# Who've } \\
\text { Watched a } \\
\text { Film Recently }\end{array}$ & $\begin{array}{l}\text { \# Who } \\
\text { are } \\
\text { Aware } \\
\text { of Indie } \\
\text { Films }\end{array}$ & $\begin{array}{l}\text { \# Who've } \\
\text { Watched } \\
\text { an Indie } \\
\text { Film } \\
\text { Before }\end{array}$ \\
\hline Yes & $95.40 \%$ & $71.71 \%$ & $100 \%$ & $84.9 \%$ & $78.3 \%$ \\
\hline No & $4.60 \%$ & $28.29 \%$ & & $15.1 \%$ & $21.7 \%$ \\
\hline
\end{tabular}

As shown in Table I, Almost all of the respondents like watching films in general, with $100 \%$ of the respondents having watched at least one film recently. In fact $95.4 \%$ answered yes and $71.7 \%$ of those prefer watching films inside theaters rather than at home.

To further the reason behind their preference, is the accumulative thought of watching films within the cinema provides a much deeper, broader, and a relatively more exciting experience. And according to the data gathered from the respondents, this is due to: 1) the different atmosphere theaters provide. 2) the surround sound. 3) and the bigger screens that cinemas have.

However, the number of 'Yes' answers dwindled to one hundred and twenty nine (129) when asked if aware of Indie Films in general. And numbers lessened further to one hundred and nineteen (119) when asked if they've watched indie films before. This data lead one to concur that even if almost the whole sample group like watching films in general (mainstream), there are still some who have little to no awareness of the independent film industry.

'Indie' is a retired word when it comes to the current movement in Philippine cinema, as the independents slowly appear to be taking over the establishment [3]. 


\section{FREQUENCY OF WATCHING INDIE FILMS}

According to the tallied data no one watches independent films within a weekly basis. With that said, nine percent $(9 \%)$ watches indie films several times a month, five percent $(5 \%)$ watches only once a month, twenty five percent (25\%) watches on a yearly basis, and the sixty one percent $(61 \%)$ majority watches several times a year. It is for the reason that independent film fest happens at least just twice or thrice a year through Cinemalaya, CinePambansa and MMFF New Wave Festival.

On the other hand, the data gave four choices on where the audiences usually watch indie films: at Cultural Center of the Philippines (CCP), at film festivals, malls, and at home through internet, cable television and the like.

Twenty two percent $(22 \%)$ watch independent films at the $\mathrm{CCP}$, ten percent $(10 \%)$ watch at film festivals, twenty nine percent $(29 \%)$ watch at malls and thirty nine percent $(39 \%)$ watching at home specifically through DVD's and the internet.

\section{CONNOTATION OF INDIE FILMS}

Films about society posed as the top choice for the respondents mainly because of the notion that independent films often opt to feature more the societal struggles within a specific area. This furthers Xu Yaping's [2] claim that indie films is the genre that shows the reality of society. It normally features society as it really is. He pointed out that independent film makers and documentarians make it their goal to portray the truth, history, and reality as close to life as possible to give light on how society really is. This also compliments another item in the table that states that indie films have economic relevance.

The next most common answer would be that independent films feature more the director's self-expression or in other words "auteurism". This too supports another study, this time by Carrie Szabo [4] which details that indie films follow the Auteur Theory.

These top two connotations, make up twenty four percent $(24.14 \%)$ and twenty one percent $(21.12 \%)$ of the answers respectively. The results also show that the respondents veered away from the common stigma of indie film being poorly edited $(1.87 \%)$, badly shot $(2.81 \%)$ and mostly about homosexual relationships $(3.75 \%)$

This solidifies Isla's study [5] about the negative stigma about indie films, low cost, small scale and the like.

The auteur theory dictates that the director exercises all creative control over the flow of the film that leads to the current version of films called "director's cut". Auteurism, correlates to a director's creative vision, seemingly so as if the director is the "Author" of the film. Auteur is French for author. [4]

\section{REASONS FOR WATCHING INDIE FILMS}

\section{Figures and Tables}

With forty percent (40\%) of the overall answers, the most evident reason for watching an indie film is it uniqueness.
The different set of themes that independent films bring to the industry as opposed to the usual good versus evil, romance themed settings the mainstream films bring about.

Another apparent reason for watching the said films can be attributed to other Indie Film's success ( $26 \%$ of the answers) whether internationally or locally like Bwakaw.

While others tend to watch indie films out of curiosity (17\%).

It is also noteworthy to state that out of 152 respondents, none of them chose the director as a reason for watching independent films. This may be due to indie films having many new/first time directors.

\section{COUNTRY's READINESS FOR INDIE FILMS}

The seventy seven percent (77\%) majority agreed that the country is ready for independent films because of how society has been more accepting today than before. Furthering that the industry needs independent films to bring something new to the field.

Whereas a small twenty three percent $(23 \%)$ answered otherwise, claiming the opposite that there are still some things that people aren't ready to see and that they'd still treat other subject matters such as pink films the same as before.

A clear majority with $87 \%$ of the respondent answered "Yes, they will watch more indie films if given a chance" for the reason being that independent films provide something different story wise. According to the study made by Musikawong [6], Tioseco [3], Song [7] and Yaping [2], independent films of any restrictions are not a factor for audience's patronage for they are after the story and theme of the film. Each film can go in any creative direction, all of which are designed to mirror today's society.

\section{DISCUSSION}

The current research illustrated the perspective of Communication students in Intramuros. The researchers created several frequency tables that would give further understanding on the research's results.

Almost all the respondents are aware of independent films and all of them have watched at least one indie film before. Majority have prior knowledge on what an indie film is about. Twenty four percent (24\%) of them said independent films are films that promote director's self-expression while Twenty one percent (21\%) percent of them all agreed independent films are mirror to our society.

Majority of those who have watched an indie film sees it at their very home for the reason that independent films have a unique theme that mostly mainstream films don't have. Aside from it, the respondents agreed that the post processing or editing of indie films makes it different from the mainstream ones.

Majority of the respondents believe as well that the Philippines is ready for new kind of film viewing through indie films. 86 percent of respondents all agreed as well that they'll watch independent film whenever they'll be given a chance though only 34.4 percent of respondents would recommend it to others upon watching it. 
According to our study, the highest number of respondents agreed indie films makes people more sensitive towards social issues and problems. They tend to see how a society runs from within. [3] An indie film makes its audiences alot understanding towards social issues; to look beyond the problem and think that there is a big reason why such issues occur. [8]

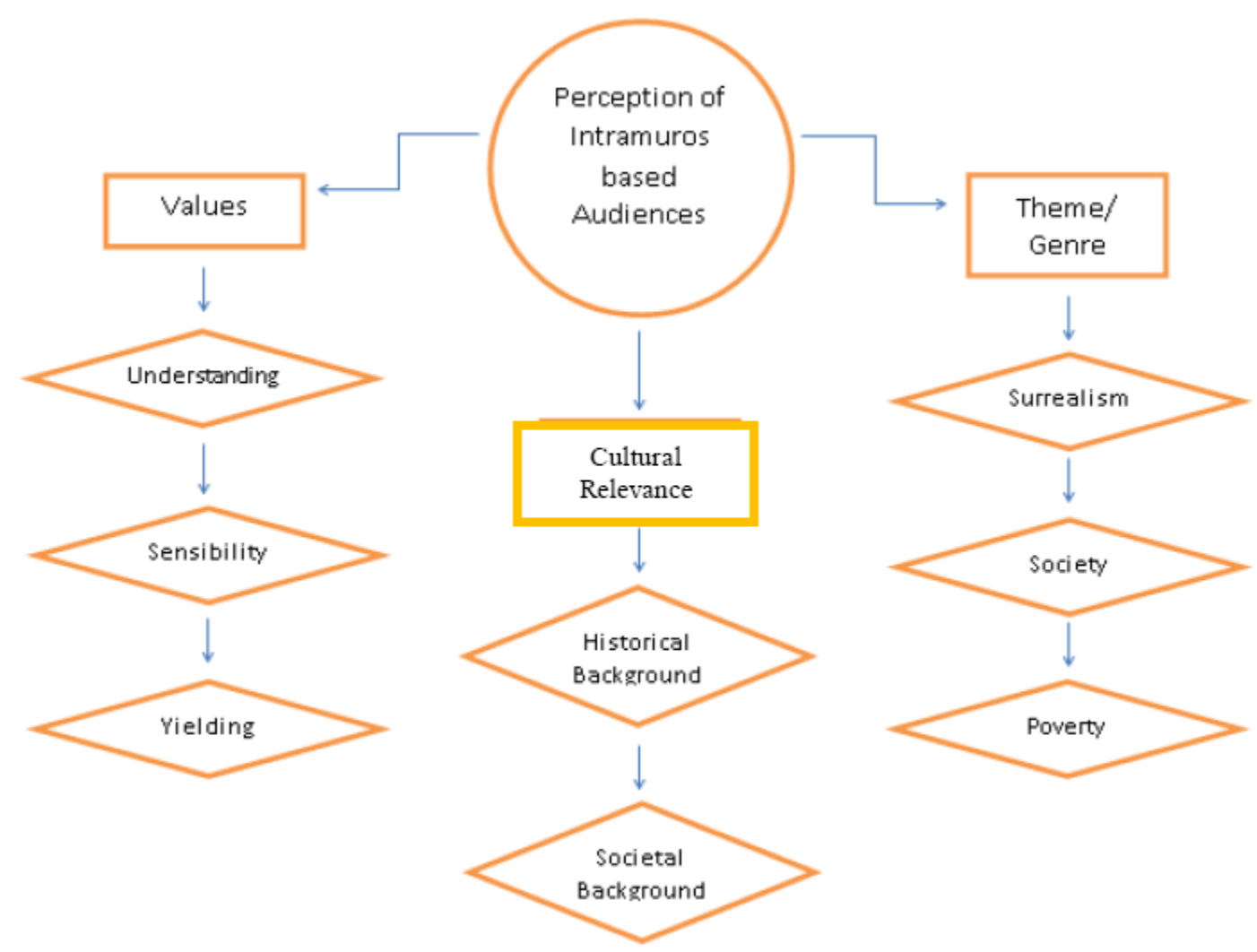

Fig. 1. The indie perception model.

Being accommodating is another value that can be learned by watching independent films. It is due to the fact that indie films teach its audiences to be more compliant and accepting towards people's opinion for they have their very reason of why they are doing it [9].

Indie films' plot/theme is one of the biggest factors why audiences watch independent films. This industry caters to a new trend on showcasing film genre and that would be the genre of surrealism. It is wherein they showcase the real society in the eyes of those who are in the slumps. (Fickers, 2008) Poverty theme is one of the most famous story plots that our indie industry caters or focuses on. Philippine cinema is in the midst of some very exciting changes, but as with any significant evolution, there are a number of serious issues that need to be addressed [3].

\section{CONCLUSION}

In conclusion, the current research results proved that the respondents perceive independent films mostly as a reflection of society and real life. The result simply utters positions on specific socio-political realities that they have experienced or observed; positions that usually contradicts rather than contribute to state driven discourse. By presenting an alternative view, subverting a dominant view, showing the opposite of what those in power claim, highlighting realities ignored in the public forum, and so on, they raise consciousness, provoke questions, but do not necessarily directly affect substantial changes in society [5].

The current research was also able to establish prospective relationships of values, plot/theme and cultural background as reasons why respondents watch independent film. There is an evident mark that correlates these three variables to impact which makes independent films impactful to their lives.

The results of the current research could fully attribute to its objectives as truly relevant to the indie films' impact to its audiences. The main objective of the current research is to test if Indie films are impactful to Intramuros based Audiences.

The study determined that the value a film instills affects its audiences. Mostly strongly agrees that independent films make people more sensible to sensitive topics. It is evident on the thesis study made by Russell [10]. Teaching people with film is a good practice. This is because film allows people to understand a certain matter better using imagery.

They concluded that film is an effective communication device as it "arouses" emotion and "stimulates" feelings. [10] The study found out that a film's plot or theme affects its audiences. Due to its story/ plot, respondents tend to become more wary of what is happening in the society. Viewers tend to watch more depending on the theme/content of the film because such films were more relevant to their lives [11].

The study proves as well that a film's relevance to one's culture affects the patronage on the independent cinema. Indie films showcase people's experiences from their culture which makes indie films much relating to its viewers. High 
relevance of indie films equals to sure success of its screening. [7] A film's cultural relevance is another factor in determining if an indie film has directly affects the life of its viewer. Most indie films that cater to the Filipinos are the ones that they could actually relate into [7].

We tend to see independent films as the mirror of our society and put it to everyone's mindset that such films are films created by reality itself without the fact of sensationalizing the real problem or issue. [4] Having almost every respondent answered that if there is a chance to watch an indie film, they would grab that opportunity for it is the time that the society embraces new trends and new industries which were already part of this generation. .

\section{ACKNOWLEDGMENT}

A most sincere thank you to our advisor Dr. Rowena Capulong Reyes, who has shown great knowledge, patience and persistence in helping improve and finish this study. Without her guidance, this study would have never been possible.

We would also like to give our appreciation to our panel members Asst. Prof. Eleanor Agulto, Asst. Prof. Carlo Miguel Francia, Mr. Rhoneil Mercado and as well as our statisticians Instructor Bryan Bulatao and Mc Dranreb Cuartero for being scrupulous in reviewing and revising our work. Their help became an integral factor in finishing our paper.

And of course our deepest gratitude to our Communications Research teacher, Asst. Prof. Odelon Gines, who has been very keen and understanding in dealing with our paper. He has exemplified great expertise in the field of research that made him a very important asset and factor that contributed to the final output of this study.

\section{REFERENCES}

[1] B. Manley, "Moving pictures: The history of early cinema," Proquest Early Popular Visual Culture, vol. 8, no. 2 pp. 189-207, May 2010.

[2] Y. Xu, "A publication of the pacific and Asian communication association," Human Communication, vol. 14, no. 3, pp. 171-181, 2010.

[3] A. Tioseco, "Shifting agendas: The decay of the mainstream and rise of the independents in the context of the Philippine cinema," Inter Asia Cultural Studies, vol. 8, no. 2, pp. 298-303, 2007.

[4] C. Szabo, "Independent mainstream and in between: How and why indie films have become their own genre," Honors College Theses, vol. 96, 2010.
[5] V. Isla, "Challlenging grand narratives on the nation: ASEAN independent filmmakers' indirect participation in development."

[6] S. Musikawong, "Working practices in Thai independent film production and distribution," Inter Asia Cultural Studies, vol. 8, 2007.

[7] T. Song, "Independent cinema in the Chinese industry," Faculty of Creative Industries, 2010.

[8] R. Yahnke, “Cinema history,” University of Minnesota, 2003, ch. 1-10.

[9] J. Garon, "Independent filmmaker's law and business guide: Financing, shooting, and distributing," Academic Collection Trial, 2009.

[10] W. Russell, "Teaching social issues with film," 2009.

[11] M. Oliver, S. Kalyanaraman, C. Mahood, and S. Ramasubramanian, "Sexual and violent imagery in movie previews: Effects on viewers' perceptions and anticipated enjoyment," Journal of Broadcasting and Electronic Media, 2007.

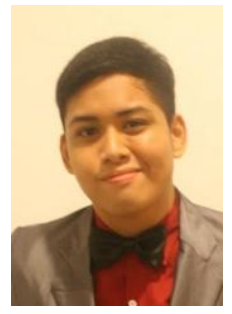

Gil Gerald N. Fuentes was born in Philippines. This Film and Television enthusiast is a graduate of Saint Mary's Angels College of Valenzuela, one of the top Marian schools in the country. And now currently in his graduating year as a Communication Arts Major in the Colegio de San Juan de Letran. He is currently the president/ managing director of Knights Television of Letran Manila, producing quality shows and events inside and outside the Colegio. Mr. Fuentes is a Philippine Catholic Mass Media nominee for the radio Public Service Announcement he directed entitled "Tradisyon Pa nga Ba?" In addition, he also produced and directed several institutional events for his college which caters mostly on Media Literacy and Environmental Awareness. He also became a bankable resource speaker through his organization's environmental programs and events. Fuentes also won several awards in his college for Best Policy Paper in Ethics, Best Television Talk program, Best Radio Documentary, and Best Radio PSA.

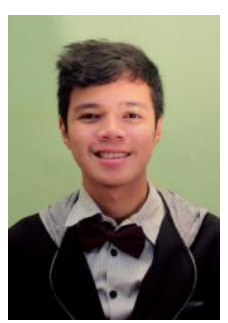

Dwight Roussel Glenn M. Labilles was born in Philippines. This young upstart is a graduate of Manila Science High School, one of the top science high schools in the country. And now currently in his graduating year as a Communication Arts Major in the Colegio de San Juan de Letran. He is a freelance event filmmaker, covering numerous birthdays and weddings throughout the years. Mr. Labilles is a Philippine Student Quill Award winner garnering an award of excellence for the documentary he directed entitled "Kawala". In addition, he also won $2^{\text {nd }}$ place in the Vaseline Pledge Hands to Save Lives Video Competition in 2012. He was also a finalist in numerous student competitions such as the Araw Values Student's Competition, AV Faith, and in the TV PSA Category of Ad Speak. Labilles also won several awards in his college for Best Policy Paper in Laws of Mass Media, Best Policy Paper in Ethics and Best Community News Paper. 